\title{
Positive Word of Mouth Marketing: Explaining the Roles of Value Congruity and Brand Love
}

\author{
- Shirkhodaie Maisam, Rastgoo-deylami Mahsa
}

\begin{abstract}
Many companies have found that for their products to be successful in the market, they must first pay for word of mouth marketing and then utilize other types of ads. Previous studies have not paid enough attention to the value of target consumers. This study evaluates the roles of value congruity, brand love, and brand image in creating a consumer commitment that leads to positive word of mouth. The sample is comprised of makeup consumers in Rasht, Iran. At first, thirty stores were selected in the city center. Then, 384 questionnaires were distributed with sampling available in selected stores. Amos 22 was used to test the conceptual model. The results show that the value congruity of the brand consumer has a positive impact on the brand image and brand commitment. Moreover, brand love and brand commitment have a significant positive impact on positive word of mouth. But the impacts of brand image and brand love on brand commitment are rejected. Also, brand image has a significant positive impact on brand love.
\end{abstract}

Keywords: brand commitment, brand image, brand love, value congruity, positive word of mouth, Iran JEL Classification: M19, M31, M37

\section{INTRODUCTION}

The industry of cosmetics is one of the most profitable industries in the world. All over the world, women with different economic and social levels consume different cosmetics (Sadeqi, 2006). Iran is one of the countries with a dynamic market of cosmetics industry. Statistics show increasing growth of selling cosmetics in Iran. Due to cosmetics smuggling in the Iranian market, the profit has been earned by the exporting countries that produce these products and globally multinational companies (Balali \& Afsharkohan, 2010). The research by statistical institute of "TMBA" shows a consuming rate of cosmetics (30\%) in Iran implied Iran as the seventh cosmetics market in the world. Among middle east countries, Iran has the second place after Saudi Arabia (Qafari Ashtiani \& Akbari, 2013). These statistics show the necessity of research on the behavior of the cosmetic's consumer in Iran. Word of mouth in the cosmetics industry and female consumers has of a paramount importance because the statistical society consists mostly of women and they are more affected by these propaganda (Shaemi \& Barari, 2011). When one decides to purchase special product according to others advice, a kind of relationship is occurred that called word of mouth marketing. In fact word of mouth is any kind of activity that passes a consumer information to the another (Gremler et al., 2001). When a product or a service is based on the needs and values of consumers, word of mouth will increase (Tuskej et al., 2013). Brand love, brand commitment, and brand image are among the factors that affect word of mouth both directly and indirectly (Tuskej et al., 2011; Unal \& Aydin, 2013; Ike-Elechi \& Tan, 2009; Albert \& Merunka, 2013). Here we investigate the effect of consumer and brand values 
on the brand image and its relation with brand and word of mouth? What is the brand love? This research aims to provide a framework to make a commitment and an increase in word of mouth by noticing the role of congruity between values of brand, the effect on the brand image, and brand love in the cosmetics industry.

\section{CONCEPTUAL BACKGROUND}

\subsection{Positive word of mouth}

Word of mouth, is talking about products and services between people apart from companies advertisement for products or services. These talks can be mutual conversations or unilateral advices and suggestions. Howevere, the main point is taking place of these talks by people who has a very low benefit to persuade others to use that product (Souiny et al., 2007). Cox states that word of mouth simply is something more than talking about products (Najmi, 2009). Word of mouth is one of the ways that has the most effect on the people and persuades people to buy a product or service more than other commercials beacause people usually trust to what they hear directly from others. In general, we need information division as a part of our relationships and tendency to hear friends', relatives ', and colleagues` advices, more than commercials from mass media (Fridman, 2007). ). Del Rio, et al., (2001) suggestion that the greater the consistency (or congruity) between the brand's image and the consumer's self image, the higher the consumer's evaluation of the brand and eventually, the higher his/her willingness to buy the brand, and values congruity through commitments would be word of mouth marketing (Larasati \& Hananto,2012).

\subsection{Values congruity}

Values are constant beliefs that transforms inherently or by personal experiences. In fact, they are the personal image of human needs that contains social interaction and social wills (Sardari Moghaddam, 2013). Values congruity is the degree of resemblance between one or a group of interlocutors of propaganda, buyers and consumers at each step of decision making that observes in the characteristics of the two sides (brand and consumer) and takes benefit of these resemblances to form the image of that structure. Structure can contain a single product, brand, shopping center or even a consumer and an advertisement (Tuskej et al., 2013). Values congruity can help improve the image (Chen et al., 2014). From among announced theories, theory of self- congruity is one of them. The theory of self-congruity shows the degree of agreement between brand and intra-personal connotations. In facts thoughts and emotions make people feel sympathy with a brand. Self- congruity refers to degree of agreement or disagreement between perception of a brand name and perception of themselves (Boksberger et al., 2011). The model used in this research is based on the Kahle approach that is known as "LOV" method and has been organized on the basis of Maslow's Hierarchy of Need and the social adaptation theory. "LOV" includes nine basic values: sense of belonging, fun and enjoyment, warm relationships with others, self-fulfillment, being well respected, excitement, security, self-respect, and sense of accomplishment. Researchs show that these nine values has been reduced to three values by analyzing factors. In this three-dimensional scale, values divide into three branches of internal, 
external, and interpersonal values (Kropp et al., 2003). According to the existing texts and the spectrum of "LOV" three kinds of values has been investigated in this article that contains external, internal, and interpersonal values. If there is an agreement between this values and brand values, the high degree of agreement will form. Three branches of values are: Internal values (self-fulfillment, self-respect and sense of accomplishment). External values (security, sense of belonging, warm relationships with others and being well respected). Interpersonal values (fun and enjoyment and excitement) (Kahle, 1983).

\subsection{Brand commitment}

Brand commitment is a psychological state that shows positive attitude of consumers toward commercial name and the will to have relationship with a product or service (Albert \& Merunka, 2013). Kanter believes that brand commitment refers to authorizing the energy and commitment to the social order. Salankik defines commitment as connecting people to the personal factors and acts, means when commitment is real; it means that people are responsible for their behavior and acts (Tavalaee \& Baqeri, 2013). Consumers with high commitment develop a strong connection with brand as well as tendency to create such connection (Walsh et al, 2010). Commitment is a multi-dimensional factor but in some research it is mentioned one-dimensional. Brand commitment can be economical, emotional, or psychological that undertakes the consumers to the commercial name. In fact commitment compromises two parts. Commitment on the basis of cost means that a person stays in a relationship because there is not any other comparable options or the cost of exchange with other options is too high, which is called continuance commitment (Albert \& Meronka, 2013). Affective commitment is different from continuance commitment; affective commitment is a kind of emotional affection to a commercial name or an organization on the basis of identification of the brand or an organization. Affective commitment of tendency to keep the relation with the brand is on the basis of the identified values. These consumers have a tendency to pay more and they use the commercial name at any situation (Tory et al., 2013). Allen and Meyer (1990) have characterized commitment as an affective and continuance. The affective commitment is based on the "affective or emotional attachment to the organization such that the strongly committed individual identifies with, is involved in, and enjoys membership in the organization. The continuance commitment in exchange relationship is built on the side bets, switching costs and scarcity of alternatives (Ziaullah et al., 2015).

\subsection{Brand image}

Brand image, is a mental image or inference for a marked product or service and contains symbolic meaning that consumers recall special characteristics of a product or service (Operia \& Back, 2008). Image is an impression perceived by the mind of a target respondent (Obamiro et al., 2014). Calling and imagination of a brand in the memory of consumers, created by the products characteristics, make the cost and attitude toward commercial name (Arsalan \& Altona, 2010). Brand image is the customers understanding of a brand that is important because of two reason. In one hand, brand image participates in the process of decision making, and at the other hand, it affects customers' succeeding behavior (Bian \& Moutinho, 2008). When there is a favorite brand image, customers will satisfy with their purchase and will be too interested in the brand; this will cause word of mouth at this respect (Unal \& Aydin, 2013; Esmaeel \& Spinly, 2012). 


\subsection{Brand love}

Brand love is a degree of exciting desirable dependency that a satisfied customer has toward a special trade name (Caroll \& Ahuvia, 2006). The amount of brand love contains two aspects of fad and interest into brand. Passion and affection are two factors determining love between two persons and appears as a kind of dimension and stages or kinds of love in the past researches (Shirkhodaei \& Nabizade, 2011).

Brand affection: Affection is defined as an intimacy (Hotfield, 1988), or dependency (Fischer, 2006). Dependency is an element that shows interest or intimacy. For example (Sternberg, 1977) defines intimacy as: feeling closeness, attachment and devotion in the love issue (Albert et al, 2008). Albert et al, (2008) presents a measure to assess brand affection that contains the secondary element of brand love in relation to 5 primary elements, as follows: Brand intimacy, dream about brand, term of relationship, brand memories, and brand uniqueness (Shirkhodaei \& Nabizade, 2011).

- Brand intimacy: Bauer \& Heinrich (2006) claim that Sternberg defines intimacy as closeness, friendliness and attachment in the relationship between people.

- Brand dream: devoted customers reveal or they show their dreams about a brand, which also state the dominant presence of brand in their minds. In the interpersonal relations, there is a relationship between love and thinking about partner. The duration of thinking about partner is a good sign of future love.

- Term of relationship: Albert et al., (2008), state that the duration of relation with a brand depends on the intimacy which refers to the depth of familiarity to the partner, which is a result of living together for a long time. This long -lasting relation shows the degree of satisfaction.

- Brand memories: A brand can revitalize positive and important memories in consumers or it can be a feeling of nostalgia (historic, childhood, the first). This is a special element of nonhuman love, because there is no sign of it in the inter-personal love theories.

- Brand uniqueness: The obtained results of opinion poll showed that the brand have chosen differently or unique, they may relate to the feeling of idealization that has been pointed out in most of the theories of inter-personal relations (Shirkhodaei \& Nabizade, 2011).

Brand passion: Albert et al., (2010) consider brand passion as a psychological structure on the basis of interpersonal investigations, and defines it as a brand fad, brand enthusiasm, frenzy, or even a consumer's complex toward a brand. Albert et al., (2008), in the assessment of brand love, relate the secondary factor of brand passion to the two basic factors consisting of Brand pleasure and brand idealization.

- Brand pleasure: Far and Russell (1991) shows that love relates to the positive excitements like joy, and the joy itself can grow love and intimacy. In the brand love, joy has a positive effect on the duration of the relationship.

- Brand idealization: Idealization means to idealize, ideal perfectionism and showing off. So, the costumers can imagine a brand as their highest wishes, consequently they can trust the brand as having an excellent position at their minds (Shirkhodaei \& Nabizade, 2011). 


\section{PREVIOUS RESEARCHES}

Table 1 shows a summary of previous research.

Tab. 1 - Previous researches, Source: Motahari nezhad (2014), Tuskej et al., (2013), Bachman \& Wilkins (2014), Tavakoli lilan (2013), Unal \& Aydin (2013), Albert \& Merunka (2013), IkeElechi \& Tan (2009).

1. Motahari nezhad (2014) investigated the
relationship between brand and consumers.
The statistical population was consumers
of electrical home appliances in Mashhad.
The results showed that brand experience
has a positive and meaningful effect on the
brand satisfaction, brand trust, brand com-
mitment and brand love. In addition, brand
satisfaction and brand trust have a positive
and meaningful effect on the brand love and
brand commitment. Brand love and brand
commitment have a positive and meaningful
effect on the word of mouth and faithfulness
to the brand.

3. Bachman \& Wilkins (2014), investigated brand commitment and customer's identification of brand as a faithfulness and intention of buying. The intention of research was that assessing the effect of these factors on the intention of buying and word of mouth of the brand. The results showed that self-congruity has not any direct effect on commitment. Customer's identification of brand has an effect on the affective commitment but it has not any continuance effect on commitment. However, commitment has a meaningful and continuance commitment effect on the word of mouth marketing. Affective commitment has not any effect on the intention of buying, but continuance commitment has a meaningful and positive effect on the intention of buying.
2. Tuskej et al., (2013), investigated the relationship between congruity of brand -consumer's value, consumer`s identity, consumer's commitment and word of mouth. Sampling method was snowball method and samples were members of social networking and the subject was their favorite brand. The results showed that the brandconsumer value`s congruity, has a positive effect on the brand commitment. It is also the consumer's identity that increases brand commitment and word of mouth about the brand. Consumer's commitment to the brand increases word of mouth about brand and has a positive effect on it.

4. Tavakoli lilan (2013) investigated the relationship between brand love, brand stimulation and image on the word of mouth. Statistical population was consumers of brand clothing and automotive industry in Mashhad. The results showed that stimulation had an effect on the brand image and brand love, but it had no effect on the mouth marketing. But, since brand love has an effect on the mouth marketing, it is worth noting that stimulation has an indirect effect on word of mouth by brand love. Also brand image has an effect on the brand love and has not any direct effect on word of mouth; in the other words brand image has an indirect effect on the word of mouth by brand love. 
5. Unal \& Aydin (2013), investigated the factors affecting brand love. Data were collected from among students of Ataturk University. Results show that brand interest has a meaningful and positive effect on the brand faithfulness and word of mouth marketing. Also brand image and self-sociality have a positive effect on the brand love but variation has not any meaningful effect on the brand interest; In fact, it has a negative effect on the brand faithfulness.

7. Ike-Elechi \& Tan (2009) investigated the effect of brand image on brand faithfulness and brand commitment in China. Statistical population was chosen from cities of Chicago and Si Chuan. Behavioral analysis showed that brand image has a positive and meaningful effect on the customers interest and commitment to the brand, and this favorite image has a longitudinal effect on the customer's mental image about quality of the brands and produces satisfaction and commitment to the brand.
6. Albert \& Merunka (2013), investigated the effect of brand love on the consumer's relationship with brand. The results reveal a strong connection between two former factors (brand identity and brand trust) with brand love and three proceeding factors of (word of mouth, paying high prices, brand commitment) with brand love. It is also confirmed the meaningful effect of commitment on word of mouth.

\section{RESEARCH MODEL AND HYPOTHESES}

Figure 1 shows the conceptual model of the research. This model is based on Tuskej et al., (2013), Unal \& Aydin (2013), Ike-Elechi \& Tan (2009), and Albert \& Moronka (2013). In the first study, Tuskej et al (2013) investigate the relationship between values` congruity, consumers` brand identification, brand commitment, and word of mouth. They show that values` congruity has a positive influence on brand commitment, and brand commitment has a positive influence on positive word of mouth. Hypotheses 3 and 7 have been stated on the basis of the results of this study.

Hypothesis 3: values`congruity has a positive influence on consumers`commitment to a brand.

Hypothesis 7: Brand commitment has a positive influence on positive word of mouth. In the second study, Unal \& Aydin investigate factors affecting brand love and concluded that brand image has an effect on the word of mouth by brand love. Hypotheses 2 and 6 were resulted according to the feedback of this study.

Hypothesis 2: Brand image has a positive influence on brand love.

Hypothesis 6: Brand love has a positive influence on positive word of mouth. Ike-Elechi and Tan's model shows the effect of brand image on the brand faithfulness and brand commitment 
in China and concluded that brand image has an effect on the brand commitment, hypothesis 4, has been stated on the basis of the results of this study.

Hypothesis 4: Brand image has a positive influence on brand commitment. Finally in the Albert and Moronka's study shows that brand love has a positive influence on brand commitment and hypothesis 5 developed.

Hypothesis 5: Brand love has a positive influence on brand commitment. According to the researches about consumers'values, and their effects on the brand perception, hypothesis 1 considered as an innovation that we can investigate the degree of congruity between brand-consumer values and the brand image.

Hypothesis 1: values` congruity has a positive influence on brand image.

Therefore, by a general review on the present study, one can investigate the effect of variables on the framework of the following conceptual model.

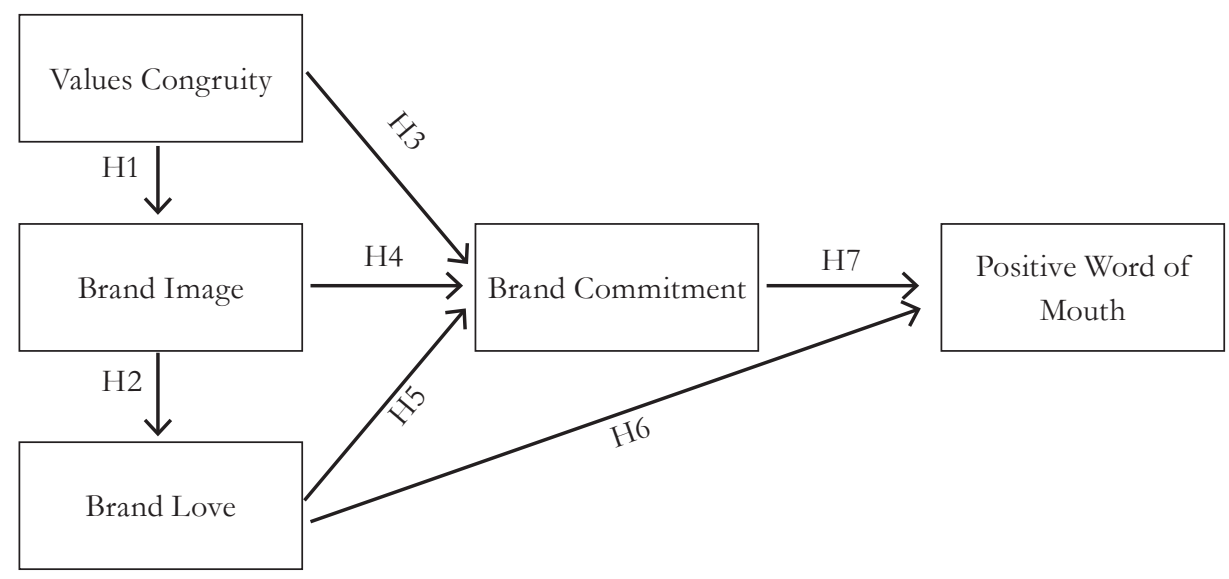

Fig. 1 - Conceptual model. Source: Tuskej et al., (2013), Unal \& Aydin (2013), Ike-Elechi \& Tan (2009), Albert \& Moronka (2013) \& Authors, (2014).

\section{RESEARCH METHODS}

This is a functional research based on the goal and data collection that investigates the relationship between variables of congruity values of brand-consumer, brand image, brand love, brand commitment, and mouth marketing. The research has been done in the spring 2014, and the statistical population was all female consumers of cosmetics (brands of My, L'Oreal, Bourjois and Classics) in Rasht, Iran. The popularity of the four brands has been selected based on a pre study through an oral questions from 30 sellers of the designated stores. The numbers of the stores have been targeted in the Rasht according to the 70 cosmetic stores identified by the trade union. Since the accumulation of the active stores in the Rasht was more than the stated number, 30 of them were chosen as a sample. To choose the best sample, the districted area was placed in the city center that is called the old downtown. The central market of Rasht is the most important 
place of trade and economic activities in the Guilan. Thousands of people from adjacent cities go there to do business (Iran deserts, 2013). Since there are historical market places in the ancient cities in Iran like Rasht, they are suitable for different classes of society to fulfill their needs. In fact people of different cultures, values, and levels of income can buy goods from these trade centers. Central markets and stores with same characteristics can reflect the better resultant of the society`s consumption. Therefore, trade investments can penetrate into ancient locals and even streets, without damaging the historical places and monuments. Nowadays, new market places and stores are built and prepared for different classes of people in the society to fulfill their needs (Jahanshahi, 2003). Consequently, the stores in city center are a good generalized resultant of statistical population.

Finally, the questionnaire was answered by customers 30 cosmetic central store that chosen by using available sampling. It means that 420 questionnaires (each store, 14 questionnaire) have been distributed and 384 of them have been valid. Since the quantity of the statistical population is unlimited, we should use the following formula to determine the quantity of samples:

$n=\frac{z_{\frac{\alpha}{2}}{ }^{2} p q}{\varepsilon^{2}}=\frac{1.96^{2} \times 0.5^{2}}{0.05^{2}}$

According to the same researches, the above formula $z_{\frac{\alpha}{2}}{ }^{2}$ considered $95 \%$ degrees of certainty, $5 \%$ of error, were 1.96 and also $\varepsilon$ were 0.05 respectively (Seyedjavadin \& Shams, 2007; Seyedjavadin et al.,2010). P is the relative characteristics in the statistical society. The amount of $\mathrm{P}$ considered 0.5 . Q is the amount of a society who has not the investigated characteristics and q equals 0.5 (1-P) (Rezvani, 2012). Therefore, the number of samples was 384. To gather the data, questionnaire inculeds two parts; the first part contains 9 questions to discover the respondents' information. The second part including investigation of positive word of mouth, brand love, brand commitment, brand image, and congruity of brand-consumer values, contains 32 questions from Likert scale, the importance determined by customers. Each respondent determines their agreement or disagreement by choosing options from completely disagree (1) to completely agree (5). It is noteworthy that the subject has been designed on the basis of the previous scientific research. Reliability and validity are characteristics of every assessing tool, like questionnaires. To determine face and content validity of the questionnaire, we use marketing and brand management experts` opinions by considering the literature and theoretical basis of the research. Then during a number of sessions, the validity of questionnaire discussed with experts with an reasonable and relevant work experiences, and their opinions have been included in the questionnaire. Also the test of confirmed analytic factor used to study the validity of the structure of research tool. At this respect the suitable analysis are RMSEA(Root Mean Square Error of Approximation), CFI(Comparative Fit Index), GFI(Goodness-of-Fit Index), TLI(Tucker-Lewis index), IFI(Incremental Fit Index), RFI(Relative Fit Index), NFI(Normed Fit Index), and Cmin/df(Chi- Square/ degree of freedom). Accordingly, a suitable model has Cmin/df amount of less than 3, RMSA less than 10\%, NFI, CFI, GFI, TLI, IFI, RFI more than $90 \%$ (Dolatabadi et al.,2012). The reliability of questionnaire determined by Cronbach`s Alpha method and using the software SPSS; during performing the test, reliability omitted from brand commitment and customers` satisfaction 
of brand. The general alpha was 0.846 , which is acceptable. It is obvious that data is reliable because the Cronbach' Alpha values are more than 0.7 .

Tab. 2 - Reliability analysis for the scales (Cronbach's alpha coefficients). Source: Raw Data Analysis

\begin{tabular}{|c|l|c|c|}
\hline $\begin{array}{c}\text { Sr. } \\
\text { No }\end{array}$ & \multicolumn{1}{|c|}{ Variable } & $\begin{array}{c}\text { Cronbach's } \\
\text { Alpha }\end{array}$ & $\begin{array}{c}\text { No } \\
\text { of items }\end{array}$ \\
\hline 1 & Value congruity & 0.756 & 8 \\
\hline 2 & Brand commitment & 0.750 & 3 \\
\hline 3 & Brand image & 0.734 & 3 \\
\hline 4 & Brand love & 0.768 & 12 \\
\hline 5 & Positive word of mouth & 0.829 & 5 \\
\hline & Total questions & 0.846 & 31 \\
\hline
\end{tabular}

Tab. 3 - Questionnaire, Source: (Kropp et al., 2003), (Aaker, 1996), (Villarejo, 2002), (Albert et al., 2008), (Shirkhodaie \& Nabizade, 2011), (Tuskej et al., 2013), (Papista \& Dimitriadis, 2012), (Zhou et al., 2013), (Kunzel \& Halliday, 2008), (Sichtmann, 2007)

\begin{tabular}{|c|c|c|c|}
\hline Source & Index & Aspect & Varibles \\
\hline \multirow{3}{*}{ 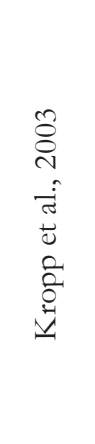 } & $\begin{array}{l}\text { I feel a sense of belonging by using this brand. } \\
\text { Using this brand makes me feel respected. } \\
\text { Using this brand equals security. }\end{array}$ & External values & \multirow{3}{*}{ 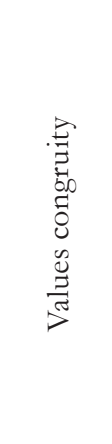 } \\
\hline & $\begin{array}{l}\text { Using this brand equals sense of self-fulfillment. } \\
\text { Using this brand equals sense of } \\
\text { accomplishment. } \\
\text { Using this brand equals sense of self-respect. }\end{array}$ & Internal values & \\
\hline & $\begin{array}{l}\text { Using this brand makes me feel fun and } \\
\text { enjoyment. } \\
\text { Using this brand equals feel of excitement. }\end{array}$ & $\begin{array}{c}\text { Inter-personal } \\
\text { values }\end{array}$ & \\
\hline 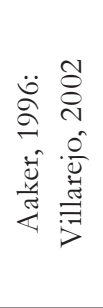 & $\begin{array}{l}\text { These products have better features compared to } \\
\text { the competitors' products. } \\
\text { This is the brand that doesn't disappoint its } \\
\text { consumers. } \\
\text { These products are usually cheaper compared } \\
\text { to the competitors' products (I feel benefit with } \\
\text { buying this brand). }\end{array}$ & - & 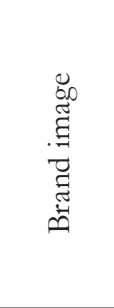 \\
\hline
\end{tabular}




\begin{tabular}{|c|c|c|c|c|}
\hline \multirow{7}{*}{ 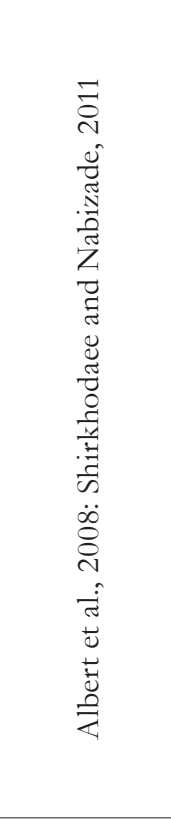 } & I take pleasure in buying and using this brand. & Pleasure & & \multirow{7}{*}{$\frac{\stackrel{0}{0}}{\vec{\sigma}}$} \\
\hline & $\begin{array}{l}\text { There is something almost ' magical' about my } \\
\text { relationship with this brand. } \\
\text { There is nothing more important to me than my } \\
\text { relationship with this brand. }\end{array}$ & Idealization & 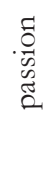 & \\
\hline & $\begin{array}{l}\text { This brand is special. } \\
\text { This brand is unique. }\end{array}$ & Uniqueness & \multirow{5}{*}{ 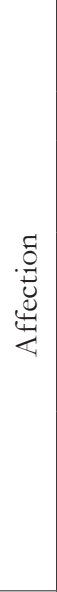 } & \\
\hline & I dream about this brand since long time ago. & Dream & & \\
\hline & $\begin{array}{l}\text { I have been using this brand for a long time and } \\
\text { I have not changed it. }\end{array}$ & Duration & & \\
\hline & $\begin{array}{l}\text { I have a warm and comfortable relationship with } \\
\text { this Brand. } \\
\text { I feel emotionally closed to this brand. I value } \\
\text { this brand in my life. }\end{array}$ & Intimacy & & \\
\hline & $\begin{array}{l}\text { This brand reminds me memories, moments of } \\
\text { my past (childhood, adolescence, a meeting, etc). } \\
\text { I associate this brand with some important } \\
\text { events of my life. }\end{array}$ & Memories & & \\
\hline 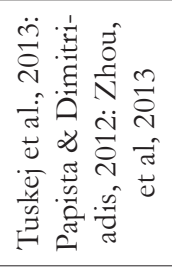 & $\begin{array}{l}\text { I want a long-term relationship with this brand. } \\
\text { If the brand disappointed me once or twice, } \\
\text { I wouldn't really mind. } \\
\text { I would be disappointed if I could not find this } \\
\text { brand in a shop. } \\
\text { I feel personally satisfied when I buy this brand. }\end{array}$ & - & & 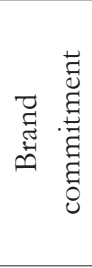 \\
\hline 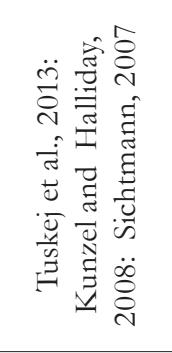 & $\begin{array}{l}\text { I give advice about this brand to people. } \\
\text { I share my personal experiences about this brand } \\
\text { to others. } \\
\text { I talk positively about this brand to my friends. } \\
\text { I will speak positively about the advantages of } \\
\text { this brand. } \\
\text { I will actually recommend this brand to my } \\
\text { friends. }\end{array}$ & - & & 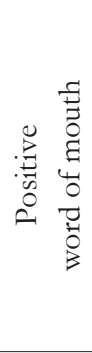 \\
\hline
\end{tabular}

To analyze the data and assess research theories, we used factor analysis test and structural equation model by Amos software.

\section{DATA ANALYSIS AND RESULTS}

\subsection{Respondents' profile}

Sample characteristics of age, marriage, education, carrier, salary, income level, costs, the favorite brand, and the amount of cosmetic use have been investigated. According to the collected data we can frankly say that most of the cosmetic consumers in Rasht are young ladies whose 
age ranges from 21 to 30 year (54\%). Gathered data shows that almost $40 \%$ of consumers have a bachelor degree, $26 \%$ of them have a M.A degree and higher. Married and unmarried customers use the same amount of cosmetics, i.e, $54 \%$ of them are unmarried and $40 \%$ of them are married. According to the official statistics in 2010, every female consumer from 15 to 45 year, cost 1440000 Rials (12000 per month) to buy cosmetics in average. Results show that most people spend 500000 to 1000000 Rials to buy cosmetics each year, which is $40 \%$ of the statistical population. About 30\%, spend less than 500000 Rials, and the rest (30\%) pay more than 1000000 Rials for cosmetics each year. By considering the percentage, results of employed and unemployed people were the same, employed ones were $43 \%$ and unemployed ones were $57 \%$ of cosmetics` users. Out of 165 employed people (43\%), 54\% of them had income level of less than 6000000 Rials and 53\% had an income range between 6000000 to 10000000 Rials. Among obtained results, most cosmetics users had an income level of 6000000 to 10000000 Rials that contain $30.5 \%$ of all users and $27.6 \%$ had an income level of 10000000 to 20000000 Rials. According to the costs and incomes, $39.8 \%$ of users stated that their use of cosmetics were average, although this is a relative and subjective scale and may differ from each person to the other. Finally, the results showe that most of the users, including $40 \%$ of the population use MY brand and the rest of them uses Bourjois, L'Oreal, and Classic brands.

\subsection{Correlation Analysis}

Correlation analysis has been applied to assess the possible association between each component variables: Brand commitment, brand image, brand love, value congruity, positive word of mouth. $\mathrm{R}$ is significant beyond the 1percent level (0.01) as shown in table (4).

Tab. 4 - Correlation between brand commitment, brand image, brand love, value congruity, positive word of mouth. Source: Raw Data Analysis

\begin{tabular}{|l|c|c|c|c|c|}
\cline { 2 - 6 } \multicolumn{1}{c|}{} & $\begin{array}{c}\text { Value } \\
\text { Congruity }\end{array}$ & $\begin{array}{c}\text { Brand } \\
\text { Image }\end{array}$ & $\begin{array}{c}\text { Brand } \\
\text { love }\end{array}$ & $\begin{array}{c}\text { Brand } \\
\text { commitment }\end{array}$ & $\begin{array}{c}\text { Positive word } \\
\text { of mouth }\end{array}$ \\
\hline Value Congruity & 1 & - & - & - & - \\
\hline Brand Image & 0.608 & 1 & - & - & - \\
\hline Brand love & 0.729 & 0.638 & 1 & - & - \\
\hline Brand commitment & 0.625 & 0.413 & 0.457 & 1 & 1 \\
\hline Positive word of mouth & 0.463 & 0.472 & 0.572 & 0.558 & \\
\hline $\begin{array}{l}\text { Note: Correlation is significant at the } 0.01 \text { level (2-tailed) } \\
\text { N=384 and Sig. (2-tailed) }=0.000\end{array}$
\end{tabular}

\subsection{Confirmative factor analysis test}

Factor analysis test is used to identify the validity of research variable structures. According to the scale of the table (5), overall indices show fine capabilities of samples by data, in the other words, the gathered data can support the structure in a good way. 
Tab. 5 - results of factor analysis. Source: Raw Data Analysis

\begin{tabular}{|c|c|c|c|c|c|c|c|c|}
\hline $\begin{array}{c}\text { Cmin/ } \\
\mathrm{df}\end{array}$ & $\begin{array}{c}\text { RM- } \\
\text { SEA }\end{array}$ & CFI & TLI & IFI & RFI & NFI & GFI & $\begin{array}{c}\text { Index / Variable`s } \\
\text { name }\end{array}$ \\
\hline 1.655 & 0.043 & 0.947 & 0.957 & 0.974 & 0.903 & 0.938 & 0.981 & Values congruity \\
\hline- & - & 1.00 & - & 1.00 & - & 1.00 & 1.00 & Brand image \\
\hline 2.736 & 0.072 & 0.941 & 0.927 & 0.942 & 0.901 & 0.911 & 0.936 & Brand love \\
\hline- & - & 1.00 & - & 1.00 & - & 1.00 & 1.00 & $\begin{array}{c}\text { Brand commit- } \\
\text { ment }\end{array}$ \\
\hline 2.736 & 0.086 & 0.973 & 0.945 & 0.973 & 0.926 & 0.963 & 0.980 & \begin{tabular}{c} 
Word of mouth \\
\hline$<3$
\end{tabular} \\
\hline$<0.1$ & $>90 \%$ & $>90 \%$ & $>90 \%$ & $>90 \%$ & $>90 \%$ & $>90 \%$ & $\begin{array}{c}\text { Accepted suit- } \\
\text { ability }\end{array}$ \\
\hline
\end{tabular}

After using factor analysis, research theories were tested on if there is an effect relationship between variables by using structural equations model, aiming at testing conceptual model of research. In summary, Table (6) shows details of our testing seven hypotheses of the survey.

Tab. 6 - Results of testing hypotheses. Source: Raw Data Analysis

\begin{tabular}{|c|c|c|c|c|c|}
\hline & Hypothesis & C.R. & $\begin{array}{c}\text { Path } \\
\text { coefficient }\end{array}$ & $\mathrm{P}$ & $\begin{array}{l}\text { Hypothesis } \\
\text { result }\end{array}$ \\
\hline 1 & $\begin{array}{l}\text { Values congruity has a positive influ- } \\
\text { ence on the brand image. }\end{array}$ & 0.31 & 4.45 & $* * *$ & Supported \\
\hline 2 & $\begin{array}{l}\text { Brand image has a positive influence } \\
\text { on brand love. }\end{array}$ & 0.56 & 7.16 & $* * *$ & Supported \\
\hline 3 & $\begin{array}{l}\text { Values congruity has a positive influ- } \\
\text { ence on brand commitment. }\end{array}$ & 0.48 & 6.15 & $* * *$ & Supported \\
\hline 4 & $\begin{array}{l}\text { Brand image has a positive influence } \\
\text { on brand commitment. }\end{array}$ & 0.07 & 0.804 & 0.421 & Not Supported \\
\hline 5 & $\begin{array}{c}\text { Brand love has a positive influence } \\
\text { on brand commitment. }\end{array}$ & 0.09 & 1.12 & 0.261 & Not Supported \\
\hline 6 & $\begin{array}{c}\text { Brand love has a positive influence on } \\
\text { positive word of mouth. }\end{array}$ & 0.44 & 6.19 & $* * *$ & Supported \\
\hline 7 & $\begin{array}{l}\text { Brand commitment has a positive } \\
\text { influence on positive word of mouth. }\end{array}$ & 0.46 & 6.88 & $* * *$ & Supported \\
\hline
\end{tabular}

According to the testing of the first hypothesis, values` congruity is formed on the basis of customers` viewpoint that compromises of external, internal, and interpersonal values, and has a positive influence on the customers` belief of brand image. It shows that the more external, internal, and inter-personal values congruity between cosmetic customers' increases, the better 
brand image forms in customers. In the second hypothesis, it is shown that brand image has a positive influence on the brand love, which means: the better brand image cause more joy that leads buying that brand and have more passion using the product. In the third hypothesis, it is stated that the congruity between brand and customers values, has a positive influence on the brand commitment that means: the better customers feel buying cosmetic brands, brand commitment and brand interest increase. But, rejected hypothesis (number 4) shows that brand love has not any positive influence on the brand commitment. In the fifth hypothesis, it is also stated that brand image has not any positive influence on the brand commitment. The sixth hypothesis investigates the effect of the brand love on the word of mouth marketing. The results show that as much interest as consumers have to cosmetic brands, this may persuade customers to transfer their positive experiences to others. In the seventh hypothesis, the effect of brand commitment on the word of mouth has been investigated. The results confirm this hypothesis and state that the more brand commitment and brand interest increases, customers marketing about brand advantages increases. Model of suitability according to the results of table (7) is at a good state.

Tab.7 - The fit indices and analysis results of the structural model. Source: Raw Data Analysis

\begin{tabular}{|c|c|c|c|c|c|c|c|c|}
\hline Cmin/df & RMSEA & CFI & TLI & IFI & RFI & NFI & GFI & Index \\
\hline 1.999 & 0.051 & 0.953 & 0.941 & 0.953 & 0.900 & 0.910 & 0.945 & Final model \\
\hline$<3$ & $<0.1$ & $>90 \%$ & $>90 \%$ & $>90 \%$ & $>90 \%$ & $>90 \%$ & $>90 \%$ & $\begin{array}{c}\text { Accepted } \\
\text { suitability }\end{array}$ \\
\hline
\end{tabular}

The model reassessed and hypotheses 4 and 5 have been omitted from the model because they didn't confirm by the model. Figure (2) shows structural equations of conceptual model in the standard mood.

In summary, table (8) shows testing four hypotheses of the survey more detailed.

Tab. 8 - Results of testing hypotheses. Source: Raw Data Analysis

\begin{tabular}{|l|c|c|c|c|c|c|c|}
\hline $\begin{array}{l}\text { Hypothesis } \\
\text { result }\end{array}$ & P & C.R. & $\begin{array}{c}\text { Path } \\
\text { coefficient }\end{array}$ & & path & \\
\hline Supported & $* * *$ & 4.64 & 0.33 & Brand image & $\leftarrow$ & Values congruity & 1 \\
\hline Supported & $* * *$ & 7.23 & 0.56 & Brand love & $\leftarrow$ & Brand image & 2 \\
\hline Supported & $* * *$ & 6.81 & 0.53 & Brand commitment & $\leftarrow$ & Values congruity & 3 \\
\hline Supported & $* * *$ & 7.20 & 0.46 & Word of mouth & $\leftarrow$ & Brand love & 6 \\
\hline Supported & $* * *$ & 7.06 & 0.47 & Word of mouth & $\leftarrow$ & Brand commitment & 7 \\
\hline
\end{tabular}




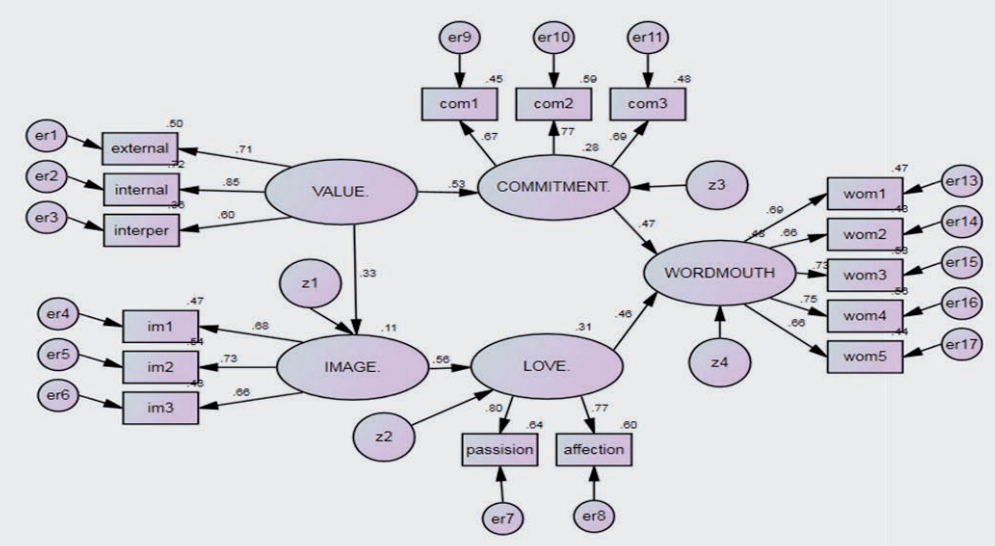

Fig. 2 - Structural equations of conceptual model in the standard mood. Source: Raw Data Analysis

Table (9) reports the Chi- Square/ degree of freedom and other suitable scales of the model's suitability and show the Root Mean Square Error of Approximation is less than $8 \%$ and the index of Chi- Square to the degree of freedom is less than three. Other suitability of this model, like Goodness-of-Fit Index, Normed Fit Index, Relative Fit Index, Incremental Fit Index, Tucker-Lewis Index, Comparative Fit Index were more than 0.9 and Root Mean Square Error of Approximation were less than 0.1 . Therefore revised model has a fine suitability and shows logical closeness to the statistical population.

Tab. 9 - The fit indices and analysis results of the structural model. Source: Raw Data Analysis

\begin{tabular}{|c|c|c|c|c|c|c|c|c|}
\hline Cmin/df & $\begin{array}{c}\text { RM- } \\
\text { SEA }\end{array}$ & CFI & TLI & IFI & RFI & NFI & GFI & Index \\
\hline 2.009 & 0.051 & 0.951 & 0.941 & 0.952 & 0.901 & 0.908 & 0.943 & $\begin{array}{c}\text { Final } \\
\text { model }\end{array}$ \\
\hline$<3$ & $<0.1$ & $>90 \%$ & $>90 \%$ & $>90 \%$ & $>90 \%$ & $>90 \%$ & $>90 \%$ & $\begin{array}{c}\text { Accepted } \\
\text { suitability }\end{array}$ \\
\hline
\end{tabular}

\section{DISCUSSION AND CONCLUSION}

Most of the research in brand image, brand commitment, brand love, and word of mouth marketing, ignored the role of personal characteristics and customers' values. But this study investigated the variables by a united model. In the recent study, the meaningful effect of congruence variable of brand and consumer's values on the brand image and commitment, and two of the mentioned hypotheses have been accepted; hypothesis 1) the effect of brand congruity on the brand image, hypothesis 3) the effect of brand congruity on the brand commitment. Although previous researches in the effect of congruence variable on the brand image, have not shown any experimental documents, the researchers claim it by relying on the texts. In fact, every commer- 
cial brand has a personality and people felt like the brand and identification with it (Kapferer, 2006). When people sympathy and kinship with a brand, they have the same values and feel closeness to the brand. This feeling can affect our mental image of a brand. Here, image has been defined as a complex of beliefs, ideas, and personal mental image of brand (Cotler, 2001). According to the hypothesis (3) in this study one can say that customers compare the products and brands with their values and mental images. When their assessment was positive and consumers feel a kind of compatibility and congruity between their values and brand values, this may effect on their attitudes, choices, satisfaction, and post-buying behaviors, like faithfulness and commitment to the brand (Tuskej et al., 2013). Numerous researches confirm the effect of brandconsumer values` congruity on brand commitments (Tuskej et al., 2013; Larasati \& Hananto, 2012; Foreman \& Whetten, 2002). In the recent study, the effect of brand image on the brand commitment has been rejected. On the other words, at the chosen time and place, there is not any meaningful relationship between brand image and brand commitment. It is not even confirmed the effect of brand image on the brand commitment by the mediator of brand love. There is a kind of combination between consumers commitment to brand and brand satisfaction and trust in most of the researches (Sahin \& Kitapsi, 2013; Bloemer et al.,1998; Bansal et al., 2004; Garbarino \& Johnson , 1999; Morgan \& Hunt,1994). According to the analysis in chapter 4, the option of consumer's satisfaction of brand, eliminated from brand commitment. It can be stated that consumers are not satisfied with it. This dissatisfaction affect the relationship between brand image and brand commitment. When there is a fine brand image, consumers will enjoy their buying and will have vertigo to the brand, which can lead to the word of mouth. In fact, hypothesis 2 (meaningful effect of brand image on brand love) and hypothesis 6 (meaningful effect of brand love on mouth marketing) are confirmed. Unal \& Aydin, 2013; Rageh Ismail and Spinelli, 2012; Tavakoli Lilan, 2012. It is also researches on the acceptance the effect of brand love on the word of mouth; Nazari et al., 2014; Wallace et al., 2014; Fetscherin, 2014; Albert and Moronka, 2013; Unal and Aydin, 2013; Yasin and Shamim, 2013. Batra et al., 2012; Rageh Ismail and Spinelli 2012; Sarkar, 2011; Bauer et al., 2007, Caroll and Ahuvia, 2006; Motahari Nejad et al., 2014; Alavi \& Siahrodi, 2014, have done researches on the effect of brand image on brand love. One way to increase word mouth marketing, more than boosting brand love and interest, is making faithful customers. In fact, organizations should mind their customers and try to keep their relationship to the brand. Hypothesis 7 (meaningful effect of brand commitment on word of mouth marketing) has been confirmed similar to the researches by Tuskej et al., 2013; Larasati and Hananto, 2012; Albert and Moronka, 2013: Hur, et al,. 2011; Sweeney and Swait 2008; Brown et al., 2005; Dick and Basu, 1994; Motahari Nejad et al.,2014; Ebrahimi and Mansori, 2013; Ahmadian, 2013; Dehdashti et al., 2010. However, Bachman and Wilkins, 2014; Kuo-Kuang and Chi-Hua 2012; Ghorbani Ghavidel and Shabgo Monsef, 2014, state that brand commitment has not any meaningful and positive effect on the word of mouth.

\section{RESEARCH SUGGESTIONS}

- Marketers should design trade mark values according to the majority of their potential and present consumers values. In fact, they have to note personal and cultural values of target consumers. They can take help from marketers to improve and design their products. 
Nevertheless they should note the possibility that consumers'values may change. In fact, there should provide situations to make a kind of overlap between brand values and consumers`values.

- Consumers with a good brand image who enjoy their purchase due to the closeness and congruity with brand, can talk with others as mouth marketers. But it may happen something wrong during a time and they lose their interest in the brand; for example, they may understand that the price increase dramatically, which may lead decreasing customers commitment and faithfulness to the brand and switching to other brands. Marketing managers should identify and settle down these impediments.

- Insisting on favorite images that were on the basis of discriminated values of brand should be company`s priority. According to the obtained results, consumers`commitment should coincide with the satisfaction and trust, to be helpful. One of the suggested approaches is that industry managers increase their products` quality to a degree of normal standards to increase their customers trust and satisfaction. Managers can make customers to propagandize and recommend the brand to others and subsequently change their tendency toward brand by increasing satisfaction, trust, and commitment to the brand.

- Marketers should invest on the boosting love relations between customers and brand. For example, by attaching celebrities to create word of mouth to the others.

- Marketers can design weblogs to gather customers' ideas and opinions and ask them talk about the brand. So, customers can talk freely about the brand.

\section{RECOMMENDATIONS FOR FURTHER RESEARCH}

Research are associated with new ideas and directions for further research toward more perfect ones. Following research topics are suggested for future researchers:

- A research with Similar topic but different statistically population or in other industries.

- Since the effect of brand image and brand love variable was rejected on brand commitment, it suggested to researchers that examine the future variable brand commitment to two different aspects (the continuous and affective commitment). In this case it will be determined whether the commitment arising from the attachment to the brand is weak in consumers or due to continuance commitment.

\section{References}

1. Aaker, D. A. (1996). Measuring Brand Equity Across Products and Markets. California Management Review, 38(3), 102-120. doi:10.2307/41165845

2. Albert, N., \& Merunka, D. (2013). The role of brand love in consumer-brand relationships. Journal of Consumer Marketing, 30(3), 258-266. doi:10.1108/07363761311328928

3. Bachman, K., \& Wilkins, S. (2014). Brand commitment and consumer--brand Identification as Determinants of consumers' brand loyalty and repurchase intentions. Research with Plymouth University, 11-32. 
4. Bansal, H. S., Irving, P. G., \& Taylor, S. F. (2004). A Three - Component Model of Customer Commitment to Service Providers. Journal of the Academy of Marketing Science, 32(3), 234-250. doi:10.1177/0092070304263332

5. Bauer, H. H., Heinrich, D., \& Martin, I. (2007). How to create High Emotional consumerbrand relationships? The causalities of brand Passion. Australian and New Zealand Marketing Academy Conference, 2189-2198.

6. Bloemer, J., de Ruyter, K., \& Peeters, P. (1998). Investigating drivers of bank loyalty: the complex relationship between image, service quality and satisfaction, International Journal of Bank Marketing, 16(7), 276-86. doi:10.1108/02652329810245984

7. Brown, T.J., Barry, T. E., Dacin, P.A. \& Gunst, R.F. (2005). Spreading the word investigating antecedents of consumer's positive word-of-mouth intentions and behaviors in a retailing context. Journal of the Academy of Marketing Science, 33(2), 123-138. doi:10.1177/00 92070304268417

8. Carroll, B. A., \& Ahuvia, A.C. (2006). Some antecedents and outcomes of brand love. Market Letter, 17(2), 79-89. doi:10.1007/s11002-006-4219-2

9. Chen, H.-B., Yeh, S.-S., \& Huan, T.-C. (2014). Nostalgic emotion, experiential value, brand image, and consumption intentions of customers of nostalgic-themed restaurants, Journal of Business Research, 67, 354-360. doi:10.1016/j.jbusres.2013.01.003

10. Chu, K.-K., \& Li, C.-H. (2012). The study of the effects of identity-related Judgment, affective identification and continuance commitment on WOM behavior, Quality \& Quantity. International Journal of Methodology, 46(1), 221-236. doi:10.1007/s11135-010-9355-3

11. Cox, D.F., \& Bauer, R.A. (1964). Self-confidence and persuasibility in women, Public Opinion Quarterly, 28(3), 453-466. doi:10.1086/267266

12. Dick, A. S., \& Basu, K. (1994). Customer loyalty: toward an integrated conceptual framework, Journal of the Academy of Marketing Science, 22(2), 99-113. doi:10.1177/0092070394 222001

13. Ebrahimi, A., \& Mansoori, S. h. (2013). Investigation of mental image of brand and service qualities on the relational marketing and customers` behavioral tendencies. Business administration, 4, 153-170.

14. Fetscherin, M. (2014). What type of relationship do we have with loved brands? Journal of Consumer Marketing, 31(6/7), 430-440. doi:10.1108/jcm-05-2014-0969

15. Garbarino, E., \& Johnson, M. S. (1999). The different roles of satisfaction, trust, and commitment in customer relationships. Journal of Marketing, 63(2), 70-87. doi:10.2307/1251946

16. Hur, W. M., Ahn, K., \& Kim, M. (2011). Building Brand loyalty through managing brand community commitment. Management Decision, 49 (7), 1194-1213. doi:10.1108/002517411111 51217

17. Johar, J. S., Sirgy J. (1991). Value-expressive versus utilitarian advertising appeals: when and why to use which appeal. Journal of Advertising, 20(3), 23-33. doi:10.1080/00913367.1991.106 73345 
18. Kahle, L. R. (1983). Social Values and Social Change: Adaptation to Life in America, Praeger, New York, NY.

19. Kropp, F., Lavack, A. M., \& Silvera, D. H. (2003). Values and collective self-esteem as predictors of consumer susceptibility to interpersonal influence among university students. International Marketing Review, 22(1), 7-33. doi:10.1108/02651330510581154

20. Kuenzel, S., \& Vaux Halliday, S. (2008). Investigating antecedents and consequences of brand identification. The Journal of Product and Brand Management, 17(5), 293-304.doi:10.1108/ 10610420810896059

21. Larasati, Y., \& Hananto, A. (2012). The Role of Value congruity and Consumer Brand Identification toward Development of Brand Commitment and Positive Word of Mouth. Electronic copy available at: http://ssrn.com/abstract=2200313. doi:10.2139/ssrn.2200313

22. Liang, W. (2011). The dimensions of consumer Commitment and its impact on brand price loyalty. Empirical study of coffee chain store brands, 12-24. 2011 International Conference on EBusiness and E-Government (ICEE). doi:10.1109/icebeg.2011.5881409

23. Morgan R. M., \& Hunt, S. D. (1994). The commitment-trust theory of relationship management. Journal of Marketing, 58(3), 20-38. doi:10.2307/1252308

24. Motahari Nejad, F., Samadi, S., Tolabi, Z., \& Allah pour A. Y., (2014). Investigation of brand-consumer relationship: Study item: Electrical appliances. Market management magazine, 23, 24-38.

25. Müge Arslan, F., \& Korkut Altuna, O. (2010). The effect of brand extensions on product brand image. Journal of Product \& Brand Management, 19(3), 170-180. doi:10.1108/1061042101 1046157

26. Nabizade, Z., (2011). Investigation of brand love in the customers and its effect on the faithfulness: Study item; Mazandaran province. MA thesis, Non- profit institute of higher education of Noor-eToba.

27. Obamiro, J. K., Ogunnaike O. O., \& Osibanjo. O. A., (2014). Organizational Citizenship Behaviour, Hospital Corporate Image and Performance. Journal of Competitiveness, 6(1), 36 - 49. doi:10.7441/joc. 2014.01.0

28. Ogba, I., \& Tan, Z. (2009). Exploring the impact of brand image on customer loyalty and commitment in China. Journal of Technology Management in China, 4(2), 132-144. doi:10.1108/17 468770910964993

29. Papista, E., \& Dimitriadis, S. (2012). Exploring consumer-brand relationship quality and identification: Qualitative evidence from cosmetics brands Qualitative Market Research. An International Journal, 15(1), 33-56. doi:10.1108/13522751211191982

30. Rageh Ismail, A., \& Spinelli, G. (2012). Effects of brand love, personality and image on word of mouth the case of fashion brands among young consumers. Journal of Fashion Marketing and Management, 16(4), 386-398. doi:10.1108/13612021211265791

31. Sadeghpoor, B., \& Moradi, V. (2010). Statistical analysis with SPSS and Amos softwares (publication, 18). Babolsar: Mazandaran University.

32. Sardari Moghaddam, M., (2013). Investigation of personal values and consumers` habits on their purchasing satisfaction. Market engineering development, 10-34. 
33. Sarkar, A. (2011). Romancing with a brand: a conceptual analysis of romantic consumerbrand relationship. Management \& Marketing journal, 6 (1), 79-94.

34. Sichtmann, C. (2007). An analysis of antecedents and consequences of trust in a corporate brand. European Journal of Marketing, 41(9/10), 999-1015. doi:10.1108/03090560710773318

35. Sweeny, J. C., Soutar, G. N., \& Mazzarol, T. (2007). Factors influencing word of mouth effectiveness: receiver perspectives. European Journal of Marketing, 42(3/4), 344-364. doi:10.11 08/03090560810852977

36. Tuskej, U., Golob, U., \& Podnar, K. (2013). The role of consumer-brand identification in building brand relationships. Journal of Business Research, 66(1), 53-59. doi:10.1016/ j.jbusres.2011.07.022

37. Unal, S., Aydin, H. (2013). An Investigation on the Evaluation of the Factors Affecting Brand Love. Procedia - Social and Behavioral Sciences, 92, 76-85. doi:10.1016/ j.sbspro.2013.08.640

38. Villarejo, A., (2002). Measuring Brand Value in the Field of Management Marketing. CEADE, Sevilla.

39. Wallace, E., Buil, I., \& de Chernatony, L. (2014). Consumer engagement with selfexpressive brands: brand love and WOM outcomes, Journal of Product \& Brand Management, 23(1), 33-42. doi:10.1108/jpbm-06-2013-0326

40. Walsh, M. F., Page Winterich, K., \& Mittal, V. (2010). Do logo redesigns help or hurt your brand? The role of brand commitment. Journal of Product \& Brand Management, 19(2), pp.76-84. doi:10.1108/10610421011033421

41. Zhou, Z., Zhang, Q. Su, C., \& Zhou, N. (2012). How do brand communities generate brand relationships? Intermediate mechanisms. Journal of Business Research, 65, 890-895. doi:10.1016/j.jbusres.2011.06.034

42. Ziaullah, M., Feng, Y., Akhter, S. N., \& Ahmad, S. (2015). An Investigation of Justice in Supply Chain Trust and Relationship Commitment - An Empirical Study of Pakistan. Journal of Competitiveness, 7(1), 71 - 87. doi:10.7441/joc.2015.01.05

\section{Contact information}

Associate prof. Maisam Shirkhodaie

Mazandaran University, Faculty of Economic and Administration Science

Iran, Mazandaran

E-mail:maisamshirkhodaie@gmail.com

Mahsa Rastgoo-deylami (MSc. Student in EMBA)

Mazandaran University, Faculty of Economic and Administration Science

Iran, Mazandaran

E-mail:Rastgoo.d@gmail.com 